\title{
Investigating the Prevalence of Hepatitis Delta and Assessment of Treatment Response
}

\author{
Delta Hepatit Sıklığııın Araștırılması ve Tedavi Yanıının Değerlendirilmesi
}

\author{
(1) Pınar Ergen, (1) Fatma Yılmaz Karadağ, (1) Özlem Aydın \\ Istanbul Medeniyet University, Göztepe Training and Research Hospital, Infectious Diseases and Clinical Microbiology, Istanbul, Turkey
}

\begin{abstract}
Objectives: The purpose of this study was to investigate the seroprevalence of delta virus, assess the treatment outcomes of patients receiving treatment.

Materials and Methods: The files of patients diagnosed with chronic hepatitis B followed up between 01.01.2015 and 31.12.2019 were examined. For the patients positive for delta antibody, demographic information, hepatitis delta virus (HDV)-RNA levels, treatment information and treatment outcomes were recorded from the files. Undetectable HDV-RNA levels after treatment was considered as total virologic response.

Results: There was a delta antibody positivity in $2.9 \%(n=74)$ of the 2,548 patients positive for hepatitis B surface antigen (HBsAg). The HDV-RNA tests of 60 patients found to be positive for delta antibody could be accessed. HDV-RNA was positive in $33.3 \%(n=20 / 60)$ of these patients, while $60 \%$ among the positive ones $(n=12)$ received treatment. Among the patients who received treatment, 58.3\% $(n=7)$ were male, $41.7 \%(n=5)$ were female, and their median age was 53 (31-69) years. There was virologic response in 50\% of the patients who received treatment, while no patient displayed HBsAg seroclearance.

Conclusion: At similar rates to those in other studies conducted in Turkey, hepatitis delta seroprevalence, virologic response rate were found to be low.

Keywords: Hepatitis delta, prevalence, treatment
\end{abstract}

ÖZ

Amaç: Bu çalışmanın amacı kronik hepatit B tanılı hastalarda delta virüs seroprevalansını araştırmak, tedavi alan hastaların tedavi sonuçlarını değerlendirmekti.

Gereç ve Yöntemler: 01.01.2015-31.12.2019 tarihleri arasında takip edilen kronik hepatit B tanılı hastaların dosyaları incelendi. Delta antikor pozitif olan hastaların demografik bilgileri, hepatit delta virüsü (HDV)-RNA düzeyleri, tedavi bilgileri ve tedavi sonuçları dosyalardan kayıt edildi. Tedavi sonrası HDV-RNA saptanamaz düzeyde olması virolojik tam yanıt olarak değerlendirildi.

Bulgular: Hepatit B yüzey antijeni (HBsAg) pozitif 2.548 hastanın $\% 2,9^{\prime}$ unda $(n=74)$ delta antikor pozitifliği saptandı. Delta antikor pozitif tespit edilen 60 hastanın HDV-RNA testine ulaşıldı. Hastaların \%33,3'ünde ( $n=20 / 60)$ HDV-RNA pozitif tespit edilmiş olup bu hastaların \%60'ına ( $n=12$ ) tedavi uygulanmıştı. Tedavi uygulanan hastaların \%58,3'ü erkek ( $n=7), \% 41,7$ 'si $(n=5)$ kadın olup yaş ortanca 53 yıl (31-69) yıldı. Tedavi gören hastaların \%50'sinde virolojik yanıt gözlenirken hiçbir hastada HBsAg seroklirensi gözlenmedi. Sonuç: Türkiye'de yapılan diğer çalı̧malara benzer oranda delta hepatit seroprevalansı, virolojik yanıt oranı düşük saptanmıştır. Anahtar Kelimeler: Delta hepatit, prevalans, tedavi

Ergen P, Yılmaz Karadağ F, Aydın Ö. Investigating the Prevalence of Hepatitis Delta and Assessment of Treatment Response. Viral Hepat J. 2020;26:135-140.

\section{Introduction}

The hepatitis delta virus (HDV) is an RNA virus, which causes a hepatitis delta infection in only hepatitis B surface antigen (HBsAg)positive individuals. The virus was detected for the first time in
Italy in 1977 by Rizzetto et al. (1), (2). While delta virus infection prevalence changes from country to country, it is estimated that 15 million people around the world are infected with HDV (3). Although HDV infections are endemic in Turkey, their seroprevalence varies from region to region $(4,5)$.

Address for Correspondence: PInar Ergen MD, Medeniyet University, Göztepe Training and Research Hospital, Infectious Diseases and Clinical Microbiology, Istanbul, Turkey Phone: +90 5324321118 E-mail: pergen71@hotmail.com ORCID ID: orcid.org/0000-0003-3990-7956 Received: 07.07.2020 Accepted: 15.09.2020

${ }^{\complement}$ Copyright 2020 by Viral Hepatitis Society / Viral Hepatitis Journal published by Galenos Publishing House. 
Its form of contagiousness is similar to that of the hepatitis B virus (HBV) infection, and it is transmitted by contaminated blood and blood products, infected body fluids, vertically from the mother to the infant and horizontally. Hepatitis delta progresses with two different clinical pictures as coinfection and superinfection. When someone is infected by HDV and HBV at the same time, a co-infection develops, and the clinical condition is more severe. Superinfection develops when an individual already infected with $\mathrm{HBV}$ receives HDV later and the clinical picture is milder. The only agent that is still used in treatment is alpha interferon (6).

Our purpose in this study was to investigate the seroprevalence of hepatitis delta in patients diagnosed with hepatitis B who had been followed up at our polyclinic for the last five years and to assess the treatment responses among the patients who were treated.

\section{Materials and Methods}

The data of 2548 HBsAg-positive patients who visited our polyclinic between 01.01.2015 and 31.12.2019 were retrospectively examined. In addition to delta antibody positivity, the treatment responses of the patients who received treatment due to hepatitis delta infection were investigated. HBsAg, anti-HDV studied with the ELISA method and HDV-RNA values measured by the polymerase chain reaction method. In addition to IV drug user, men who have sex with men (MSM), human immmunodeficiency virus (HIV)/HCV co-infection, whether their partners had HDV infection or not, the patients were also evaluated in terms of co-infection, superinfection, fulminant hepatitis, cirrhosis and hepatocellular carcinoma. Assessment of the treatment response was performed based on the Turkey 2017 Clinical Practice Guidelines on Hepatitis Delta Virus Infection Diagnosis, Monitoring, Management and Treatment (7). Total virologic response was accepted as undetectable levels of HDV-RNA. Hepatitis B e antigen $(\mathrm{HBeAg}) / a n t i-H B e$, alanine aminotransferase (ALT), HBVDNA, alpha-fetoprotein, abdominal imaging and liver pathology tested at the beginning of the treatment and HDV-RNA, HBV-DNA ALT, HBsAg/anti-Hbs tested after the treatment were examined.

The study was approved by the Ethics Board of the Istanbul Medeniyet University, Göztepe Training and Research Hospital (decision no: 2020/0032, date: 21.01.2020). The study was carried out in compliance with the principles of the Declaration of Helsinki.

\section{Statistical Analysis}

Utilizing the SPSS IBM 22.0 (SPSS Inc., Chicago II) software, the data was processed. The distribution of the data was evaluated by Kolmogorov-Smirnov test. The descriptive variables are presented as frequency, percentages, mean and standard deviation, while non-normally distributed variables are expressed as median (minimum-maximum). Using chi-squared test and Fischer's exact test, comparisons were made. A p-value of smaller than 0.05 was accepted as statistically significant.

\section{Results}

Delta antibody positivity was determined in $2.9 \%(n=74)$ of the $2548 \mathrm{HBsAg}$-positive patients. 50\% of the patients $(n=37)$ were male, $50 \%(n=37)$ were female, and their median age was 51 (23-80) years. The HDV-RNA tests of 60 patients with positive delta antibody could be accessed. HDV-RNA was positive in $33.3 \%(n=20 / 60)$ of these patients, while $60 \%$ among the positive ones $(n=12)$ received treatment. Eight patients had not received treatment due to reasons such as pregnancy, being of foreign nationality and not being able to receive treatment or not coming for follow-up. Among the patients who received treatment, 58.3\% $(n=7)$ were male, $41.7 \%(n=5)$ were female, and their median age was 53 (31-69) years. The patients received at least 48 weeks of pegylated interferon (Peg-IFN) treatment. 66.7\% ( $n=8)$ of these patients received interferon only the treatment by itself, while $33.3 \% \quad(n=4)$ received a nucleoside/nucleotide analogue alongside with interferon. There was virologic response in $50 \%$ of the patients who received treatment, while no patient displayed HBsAg seroclearance or seroconversion. Fulminant hepatitis was not observed in this study, but hepatocellular carcinoma developed in one patient who received treatment and was being monitored for a long time with negative HDV-RNA. The pre-treatment and post-treatment data of the patients who received treatment, the treatment that they received and treatment durations are shown in Table 1.

\section{Discussion}

In HBsAg-positive individuals, delta infection is a condition that always needs to be kept in mind and monitored. Especially individuals born in places with high HDV endemicity, those using intravenous drugs, MSM, HCV- or HIV-infected individuals, those with multiple partners or previous history of sexually transmitted disease and individuals with high ALT values alongside low or undetectable HBV-DNA are under the risk of HDV infection (8). While none of our patients had intravenous drug use, MSM history or HIV and/or HCV positivity but the spouse of one patient had a diagnosis of hepatitis delta. Also one of our patient came from a foreign country.

In the course of HDV infection, acute hepatitis, chronic hepatitis, fulminant hepatitis, cirrhosis and hepatocellular carcinoma may appear $(2,9)$. Fulminant hepatitis was not observed in any of our patients examined in this study, while it was determined that hepatocellular carcinoma developed in one patient who received treatment and was being monitored for a long time with negative HDV-RNA (Table 1, patient no: 10). Rates of becoming chronic following superinfection are $70-90 \%$, while there are much higher in comparison to rates after coinfection $(7,10,11)$. None of our patients had acute coinfection, in all patients delta positivity was determined during their monitoring.

Turkey is a moderately endemic region in terms of delta infection, while the positivity rates show differences between the east and the west of the country (12). In the meta-analysis by Değertekin et al. (4), when the data of studies conducted after 1995 were examined, it was shown that the anti-HDV positivity rate in the west of Turkey was $4.8 \%$, while it was $27.1 \%$ in the east. In their study conducted in 2019 in Istanbul, Yolcu et al. (13) reported the anti-HDV positivity rate as $4.1 \%$. The delta positivity rate in this study was $2.9 \%$, and it was lower than those in eastern provinces and similar to those in western ones.

Studies have shown a decrease in the HDV prevalence in Turkey throughout the years. Ayaz and Sarı (14), in their study covering the period of 2012-2017, determined anti-delta positivity as 4.4\%, and 


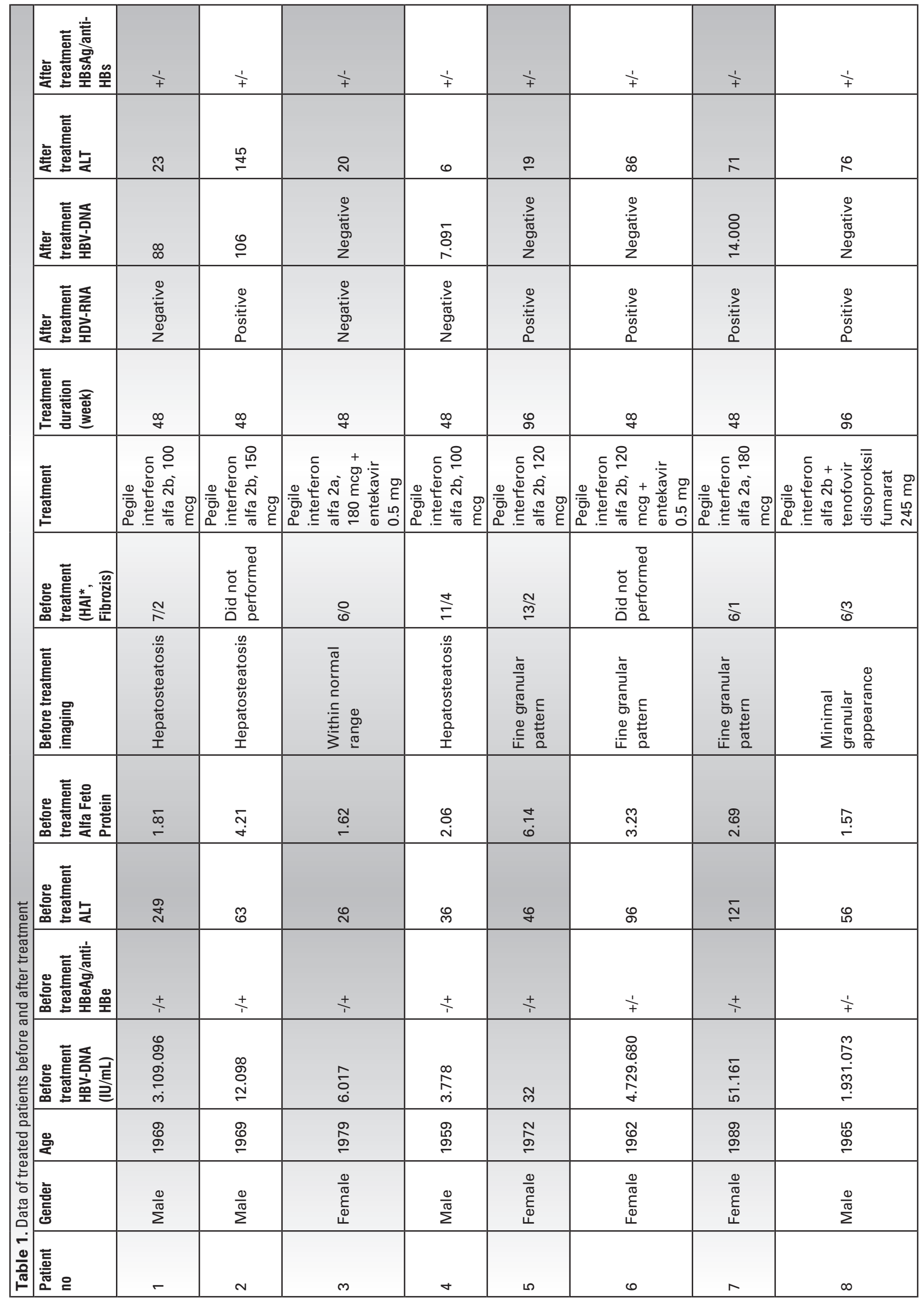




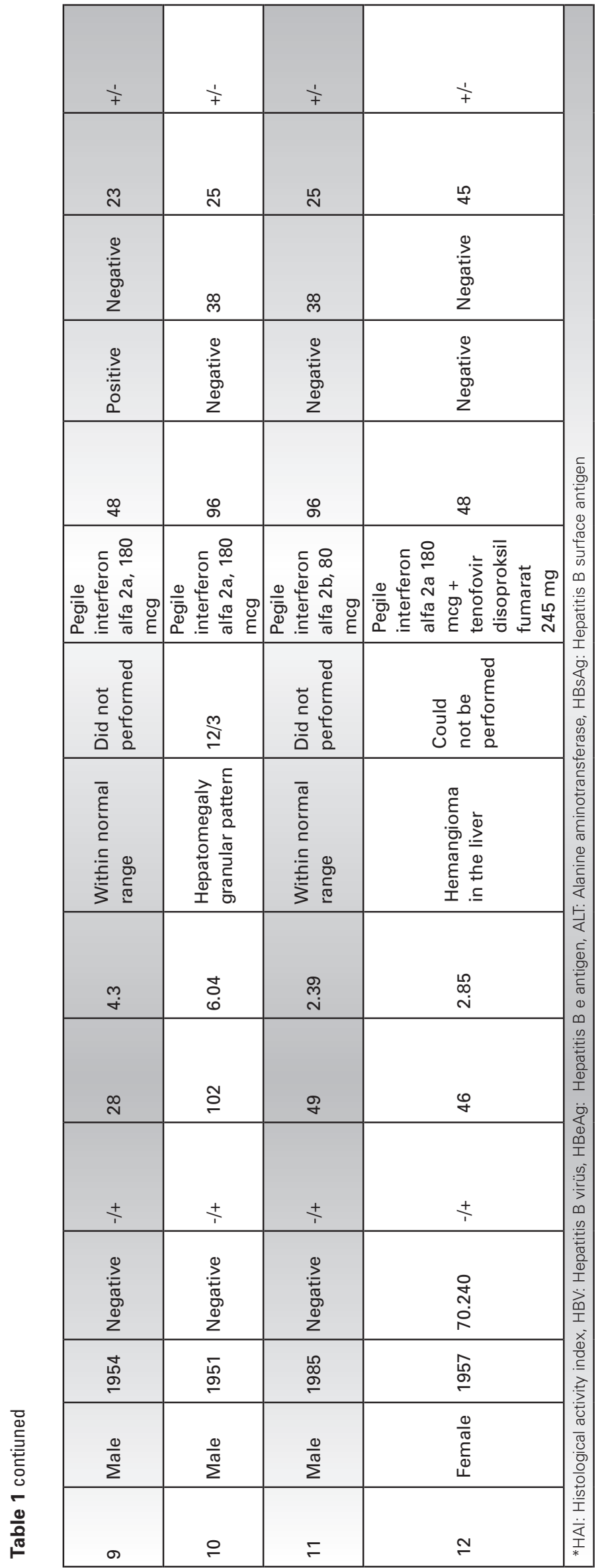

they reported that this rate was $8.52 \%$ in their study covering the period of 2002-2004 $(14,15)$. Eser-Karlıdağ (16) found the delta positivity in Elazığ in eastern Turkey as $8.8 \%$ and reported that this ratio was lower in comparison to those reported in previous studies in the region. It is an ordinary outcome that, with the addition of hepatitis B vaccination to the national vaccination program in 1998, there has been a decrease in the prevalence of chronic hepatitis $B$, therefore, the prevalence of hepatitis delta, among young adults. Despite this, as hepatitis B infections have not been eradicated, HDV still continues to be a public health problem.

While studies are going on regarding new agents including the hepatocyte entry inhibitor myrcludex B, farnesyl transferase inhibitor lonafarnib, nucleic acid polymers and Peg-IFN- $\lambda$, the only option in treatment today is still Peg-IFN- $\alpha(17,18)$. The primary target in treatment is to lower the HDV-RNA value to an undetectable level. HBsAg clearance and seroconversion are the ultimate goal, while it is highly difficult to reach this goal. Without regards to treatment response, PEG-IFN treatment must continue for 48 weeks. While reaching undetectable levels of HDV-RNA and continuation of these 6 months after the end of the treatment are desired, low rates of sustainable HDV suppression are reached after treatments of 48-96 weeks (19). For this reason, the HDVRNA negativity we obtained 6 months after the end of the treatment cannot be considered as permanent virologic response, but biochemical and virologic monitoring is recommended. In the 5-year follow-up study of HIDIT-1 by Heidrich et al. (20), at least one positivity was determined in the follow-ups of 9 of 16 patients whose HDV-RNA was determined as negative 24 weeks after the end of the treatment. Rather than IFN monotherapy, combined treatment studies are also conducted to increase the success of treatment. In the randomized controlled HIDIT-1 and HIDIT-2 studies conducted by Wedemeyer et al. (21) , (22), no significant difference could be found in the treatment responses between patients receiving IFN treatment and those receiving IFN and tenofovir disoproxil treatment. There are also other studies showing that usage of nucleoside/nucleotide analogues as monotherapy or in combination with PEG-IFN does not have an additional benefit $(23,24,25)$. Combined treatment may be recommended in patients with diagnosis of chronic hepatitis B needing treatment in addition to HDV infection. While HBV-DNA was negative after treatment in all 4 patients we gave combined therapy, only 2 patients were found to have negative HDV-RNA values.

In the review by Yurdaydin and Idilman (26), virologic success was reported as $14-50 \%$ in controlled studies conducted on patients using IFN and $17-47 \%$ in studies conducted with PEG-IFN. In our study, virologic response was determined at a rate of $50 \%$, which was similar to those reported in studies conducted in Turkey and around the world.

As eradication is out of the question as long as the presence of HBsAg continues, the necessity of HDV-RNA monitoring is clear. During the treatment of HDV which is generally dominant in HDV coinfection, HBV-DNA monitoring of patients should also be conducted (27).

\section{Study Limitations}

The limitation of the study is that it is a retrospective study, so all patient datas were not available. 


\section{Conclusion}

The primary way of preventing delta infection development is to achieve protection of under-risk individuals by applying effective vaccination programs and eradicating hepatitis $B$ infection by raising awareness in all parts of the society. All patients positive for HBsAg should be screened in terms of HDV, and patients with HDV viremia should be treated. While IFN is still the only preferred option in treatment, a more effective antiviral agent is needed.

\section{Ethics}

Ethics Committee Approval: The study was approved by the Ethics Board of the Istanbul Medeniyet University, Göztepe Training and Research Hospital (decision no: 2020/0032, date: 21.01.2020).

Informed Consent: Since our study was retrospective, informed consent was not used.

Peer-review: Externally peer-reviewed.

\section{Authorship Contributions}

Concept: P.E., F.Y.K., Ö.A., Design: P.E., Ö.A., Data Collection or Processing: P.E., Analysis or Interpretation: F.Y.K., Literature Search: Ö.A., Writing: P.E., F.Y.K.,

Conflict of Interest: Authors declare no conflict of interest. Financial Disclosure: There was no aid and sponsor for this study

\section{References}

1. Rizzetto M, Canese MG, Aricò S, Crivelli O, Trepo C, Bonino F, Verme G. Immunofluorescence detection of new antigen-antibody system (delta/anti-delta) associated to hepatitis B virus in liver and in serum of HBsAg carriers. Gut. 1977; 18:997-1003.

2. Botelho-Souza LF, Vasconcelos MPA, Dos Santos AO, Salcedo JMV, Vieira DS. Hepatitis delta: virological and clinical aspects. Virol J. 2017;14:177.

3. Hughes SA, Wedemeyer H, Harrison PM. Hepatitis delta virus Lancet. 2011:378:73-85.

4. Değertekin H, Yalçin K, Yakut M, Yurdaydin C. Seropositivity for delta hepatitis in patients with chronic hepatitis B and liver cirrhosis in Turkey: a meta-analysis. Liver Int. 2008;28:494-498.

5. Wranke A, Pinheiro Borzacov LM, Parana R, Lobato C, Hamid S, Ceausu E, Dalekos GN, Rizzetto M, Turcanu A, Niro GA, Lubna F Abbas M, Ingiliz P, Buti M, Ferenci P, Vanwolleghem T, Hayden T, Dashdorj N, Motoc A, Cornberg M, Abbas Z, Yurdaydin C, Manns MP, Wedemeyer H, Hardtke S; Hepatitis Delta International Network. Clinical and virological heterogeneity of hepatitis delta in different regions world-wide: The Hepatitis Delta International Network (HDIN). Liver Int. 2018;38:842-850.

6. Hsieh TH, Liu CJ, Chen DS, Chen PJ. Natural course and treatment of hepatitis D virus infection. J Formos Med Assoc. 2006;105:869-881

7. Yurdaydın C, Tabak F, Kaymakoğlu S, Akarsu M, Akıncı EG, Akkız H, Alkım C, Çekin AH, Çuvalcı NÖ, Demir K, Değertekin B, Dökmetas I, Ersöz G, Hizel K, Kandemir FÖ, Önlen Y, Sonsuz A Şenateş E, Tosun S, Tözün N, Idilman R, Guidelines Study Group $\mathrm{VH}$. Diagnosis, management and treatment of hepatitis delta virus infection: Turkey 2017 Clinical Practice Guidelines. Turk J Gastroenterol. 2017;28(Suppl 2):84-89.

8. Terrault NA, Lok ASF, McMahon BJ, Chang KM, Hwang JP, Jonas MM, Brown RS Jr, Bzowej NH, Wong JB. Update on prevention, diagnosis, and treatment of chronic hepatitis B: AASLD 2018 hepatitis B guidance. Hepatology. 2018;67:1560-1599.
9. Romeo $R$, Del Ninno $E$, Rumi $M$, Russo $A$, Sangiovanni $A$, de Franchis R, Ronchi G, Colombo M. A 28-year study of the course of hepatitis Delta infection: a risk factor for cirrhosis and hepatocellular carcinoma. Gastroenterology. 2009;136:1629-1638

10. Rizzetto M, Smedile A. Hepatitis D. In: Schiff ER, Sorrell M, Maddrey $W$, eds. Diseases of the Liver. Philadelphia, PA: Lippincott, Williams and Wilkins; 2002:863-875.

11. Farci P, Niro GA. Clinical features of hepatitis D. Semin Liver Dis 2012;32:228-236

12. Ayaz C, Cem Yardımcı C, Çandır N, Ersöz G, Şanlıdağ T, Tığlı A, Türken M. Management of Chronic Hepatitis D Virus Infection: A Consensus Report of the Study Group for Viral Hepatitis of the Turkish Society of Clinical Microbiology and Infectious Diseases. Klimik Dergisi 2014;27(Özel Sayı 1):40-47.

13. Yolcu A, Karabulut N, Alaçam $S$, Önel $M$, Büyük $M$, Güllüoğlu $M$, Ağaçfidan A Frequency of Hepatitis Delta Virus in Hepatitis B Surfaceantigen-positive Patients Viral Hepatit Dergisi. 2019;25:1418.

14. Ayaz C, Sarı T. Treatment results of chronic delta hepatitis patients. Ortadoğu Tıp Derg. 2019;1:77-73.

15. Celen MK, Ayaz C, Hosoglu S, Geyik MF, Ulug M. Anti-hepatitis delta virus seroprevalence and risk factors in patients with hepatitis B in Southeast Turkey. Saudi Med J. 2006;27:617-620.

16. Eser-Karlıdağ G. Prevalence of Hepatitis Delta in Chronic Hepatitis B Patients. Klimik Derg. 2019;32:281-284

17. Yurdaydin C, Abbas Z, Buti M, Cornberg M, Esteban R, Etzion O, Gane EJ, Gish RG, Glenn JS, Hamid S, Heller T, Koh C, Lampertico P, Lurie Y, Manns M, Parana R, Rizzetto M, Urban S, Wedemeyer $\mathrm{H}$; Hepatitis Delta International Network (HDIN). Treating chronic hepatitis delta: The need for surrogate markers of treatment efficacy. J Hepatol. 2019;70:1008-1015.

18. Bahcecioglu IH, Sahin A. Treatment of Delta Hepatitis: Today and in the Future - A review. 2017:49:241-250.

19. Cornberg M, Lok AS, Terrault NA, Zoulim F; 2019 EASL-AASLD HBV Treatment Endpoints Conference Faculty. Guidance for design and endpoints of clinical trials in chronic hepatitis B Report from the 2019 EASL-AASLD HBV Treatment Endpoints Conferenceł. J Hepatol. 2020;72:539-557.

20. Heidrich B, Yurdaydın C, Kabaçam G, Ratsch BA, Zachou K, Bremer B, Dalekos GN, Erhardt A, Tabak F, Yalcin K, Gürel S, Zeuzem S, Cornberg M, Bock CT, Manns MP, Wedemeyer H; HIDIT-1 Study Group. Late HDV RNA relapse after peginterferon alpha-based therapy of chronic hepatitis delta. Hepatology. 2014;60:87-97.

21. Wedemeyer H, Yurdaydin C, Dalekos GN, Erhardt A, Çakaloğlu Y, Değertekin H, Gürel S, Zeuzem S, Zachou K, Bozkaya H, Koch A, Bock T, Dienes HP, Manns MP; HIDIT Study Group. Peginterferon plus adefovir versus either drug alone for hepatitis delta. N Engl J Med. 2011;364:322-231.

22. Wedemeyer $\mathrm{H}$, Yurdaydin $\mathrm{C}$, Hardtke $\mathrm{S}$, Caruntu FA, Curescu MG, Yalcin K, Akarca US, Gürel S, Zeuzem S, Erhardt A, Lüth S, Papatheodoridis GV, Keskin O, Port K, Radu M, Celen MK, Idilman R, Weber K, Stift J, Wittkop U, Heidrich B, Mederacke I, von der Leyen $H$, Dienes HP, Cornberg $M$, Koch A, Manns MP; HIDIT-II study team. Peginterferon alfa-2a plus tenofovir disoproxil fumarate for hepatitis D (HIDIT-II): a randomised placebo controlled, phase 2 trial. Lancet Infect Dis. 2019;19:275286

23. Canbakan B, Senturk H, Tabak F, Akdogan M, Tahan V, Mert A, Sut N, Ozaras R, Midilli K, Ozbay G. Efficacy of interferon alpha-2b and lamivudine combination treatment in comparison to interferon alpha-2b alone in chronic delta hepatitis: a randomized trial. J Gastroenterol Hepatol. 2006;21:657-663.

24. Niro GA, Ciancio A, Tillman HL, Lagget $M$, Olivero A, Perri $F$ Fontana R, Little N, Campbell F, Smedile A, Manns MP, Andriulli A, Rizzetto M. Lamivudine therapy in chronic delta hepatitis: a 
multicentre randomized-controlled pilot study. Aliment Pharmaco Ther. 2005;22:227-232.

25. Niro GA, Smedile A, Ippolito AM, Ciancio A, Fontana R, Olivero A, Valvano MR, Abate ML, Gioffreda D, Caviglia GP, Rizzetto M, Andriulli A. Outcome of chronic delta hepatitis in Italy: a long-term cohort study. J Hepatol. 2010;53:834-840.
26. Yurdaydin C, Idilman R. Therapy of Delta Hepatitis. Cold Spring Harb Perspect Med. 2015;5:a021543.

27. European Association for the Study of the Liver. EASL 2017 Clinical Practice Guidelines on the management of hepatitis B virus infection. Journal of Hepatology. 2017;67:370-398. 